マウスの気管および肺ホモジネート上清液中の

Streptococcus pneumoniae 拉よび Haemophilus influenzae の増殖に関与する因子について

\author{
北矢 進 宮崎 修一 \\ 東邦大学 医学部 微生物学教室 \\ 大田区大森西 5-21-6 $\mathbf{\uparrow} 143$ \\ [受付：8月15日，1986年]
}

\begin{abstract}
Haemophilus influenzae および Streptococcus pneumoniae の普通ブイョン中の増殖に及ぼす マウスの気管および肺ホモジネート上清液の影響を検討し，次の結果を得た。

H. influenzae は気管ホモジネート上清液添加普通ブイヨンおよび $\mathrm{X} \cdot \mathrm{V}$ 両因子添加普通ブ イョンで增殖を示し, 一方, 肺ホモジネート上清液添加普通ブイョンおよび NADase (Nicotinamide adenine dinucleotide) 処理によつてV 因子を不活化した気管ホモジネート添 加普通ブイョンでは増殖しなかつた。

S. pneumoniae は肺ホモジネート上清液添加普通ブイヨンおよび V 因子添加普通ブイヨン で増殖を示し, 一方, 気管ホモジネート上清液添加普通ブイョン, $\mathrm{X} \cdot \mathrm{V}$ 両因子添加普通ブイ ヨン, 肺ホモジネート上清液と X 因子を添加した普通ブイヨン, および NADase 処理肺ホ モジネート上清液添加普通ブイョンでは增殖できなかつた。

以上の事実より，H. influenzae の增殖に必要な $\mathrm{X} \cdot \mathrm{V}$ 因子は気管ホモジネート上清液中に 存在し，この中，X 因子の存在が $S$. pneumoniae の増殖を阻害したと考えられた。また，肺 ホモジネート上清液中には両菌種の増殖に必要な V 因子は存在するが， X 因子は欠如，も しくは少量しか存在しないと考えられた。その他に肺ホモジネート上清液中には $H$. influenzae を増殖抑制する未知のたんばく物質の存在が示唆された。
\end{abstract}

呼吸器感染症発症機序に関わる因子としては, 従来, 細菌の気道粘膜上皮への付着, おょび定着機構，また， これに関連する機械的清浄機能, 肺胞マクロファージや 好中球などによる食殺菌作用を含さ免疫作用などが報告 されている2-4,8)。呼吸器感染症起炎菌のうち, 多くの臨 床例において一次感染では Streptococcus pneumoniae は 肺炎を, Haemophilus influenzae は気管または気管支炎 を起こしやすいことが報告されている3,5-7)。

しかし, 呼吸器感染症発症機序に関して, 呼吸器官と 起炎菌との特徵的な関係については，これまで解明され
ていない。松本ら ${ }^{3)}$ は, H. influenzae 呼吸器感染症は 副鼻腔炎に併発例の多いこと，慢性気管支炎や気管支払 張症に多いことから, 気道における過分泌と関連つけ, 気道分泌液中に $H$. influenzae の増殖因子の存在を推論 している。H. influenzae の増殖因子としては, すでに $\mathrm{X}$ 因子と V 因子が知られており $S$. pneumoniae の增 殖には血液成分が必要であることが知られている9)。こ の様な增殖因子を必要とする菌種は粘膜への付着の問題 を別にすれば，必要量の増殖因子が存在しなければ感染 を惹起し難いと考えられる。また，組織に菌の增殖阻害 
因子が存在すれば，菌による感染の成立は抑制されると 思われる。

著者らは, 呼吸器感染症の原因菌として分離頻度の高 、H. influenzae とS. pneumoniae が, 感染好発組織に 相違が認められることに着目し，組織中に存在する 2 菌種の增殖因子および阻害因子について検討した。

\section{材料と方法}

使用菌株：各種臨床材料由来の Haemophilus influenzae K14（血清型 b), TMS1 （血清型 b), TMS2（血 清型 c), TMS3 (血清型 a), TMS4 (型別不能), お。 よび Streptococcus pneumoniae TMS11 (血清型 1), TMS12（血清型 2), TMS13（血清型 3), TMS14（血 清型 4), TMS15 （型別不能）を使用した。

使用培地：普通寒天培地（栄研化学）および普通ブイ ョン（Oxoid）を用いた。血夜寒天培地, チョコレート 寒天培地は普通寒天培地を基礎培地とし, 馬脱瀻維素血 液（日本生物材料センター）を $10 \%$ になるよら無菌 的に加えて作製した。

試莱：Hemin, NAD (nicotinamide adenine dinucleotide), NADase, protease (以上 Sigma) を使用した。

接程菌液 : H. influenzae はチョコレート寒天平板で, S. pneumoniae は血液平板で $37 \mathrm{C}$ 一夜培湌後, 菌体を 採取し, 隇菌生理食塩水で黧濁後, 所定の菌数に調整し た。

マウス気管および肺ホモジネート上清液の調整 : 1 群 5 匹の ICR 系雄マウス（体重 $20 \pm 1 \mathrm{~g}$ ）を放血致 死後，気管と肺を採取した。それぞれに生理食塩水を $5 \mathrm{~m} l$ 加え,ポッター型ホモジナイザーにてホモジナイ ズした後， $1,500 \times g, 20$ 分間遠心し，上清をメンブラン フィルター $(0.45 \mu \mathrm{m}$ Millipore Co. $)$ にて洰過滅菌した。

マウス気管および肺ホモジネート上清液の protease 処理および NADase 処理液：上記のホモシ ネート上清液に protease および NADase を $10 \mu \mathrm{g} / \mathrm{m} l$ になるよらに添加し，37C 1 時間作用させた後，洰過 隇菌した。

Hemin と NAD の調整：Hemin（X 因子）は少量 の $1 \mathrm{~N}$ 水酸化ナトリゥム溶液に, NAD（V 因子）は生 理食塩水に溶解し，洰過減菌し，各滇度液を作製した。

增湤实験：上述の hemin 液, NAD 液, 気管および 肺ホモジネート上清液を普通ブイョン中に $10 \%(\mathrm{v} / \mathrm{v})$ 加之 H. influenzae, S. pneumoniae の $10^{2} \mathrm{CFU} / \mathrm{ml}$ を接 種, $37 \mathrm{C}$ で培㟤し各時間毎に生菌数を測定した。また, $\mathrm{V}$ 因子を $50 \mu \mathrm{g} / \mathrm{m} l$ と一定にし，X 因子を $5,0.5$,
$0.05 \mu \mathrm{g} / \mathrm{m} l$ 含む普通ブイョン，および $\mathrm{X}, \mathrm{V}$ 因子をそ れぞれ $50 \mu \mathrm{g} / \mathrm{m} l$ 含む普通ブイョンに $10 \%(\mathrm{v} / \mathrm{v})$ の肺 ホモジネート上清液を添加した培地におけり增殖性，X 因子を $50 \mu \mathrm{g} / \mathrm{m} l$ 含む普通ブイヨンに $10 \% （ \mathrm{v} / \mathrm{v} ）$ の肺 ホモジネート上清液を添加した培地に拈ける增殖性につ いても検討した。

\section{实験成縝}

H. influenzae および S. pneumoniae の增殖におよ ぼすマウス肺および気管ホモジネート上清液の効果

図1に示したように，H． influenzae およびS. pneumoniae はともに普通ブイヨンでは増殖は認められ なかつた。しかし気管ホモジネート上清夜の添加によつ て H. influenzae の増殖のみが認められ，一方，肺ホモ ジネート上清液の添加では S. pneumoniae の增殖のみ が認められた（図 1)。

H. influenzae および S. pneumoniae の增殖におけ る X 因子および V 因子の影留 :

四 2 に示したよ5に，H. influenzae は X 因子ある いは V 因子単独をそれぞれ $0.5 \sim 500 \mu \mathrm{g} / \mathrm{m} l$ 加えた普 通ブイヨン中ではまつたく増殖しなかつた。しかし X 因子および V 因子をともに $0.5 \mu \mathrm{g} / \mathrm{m} l$ 添加した普通ブ イョンでは 24 時間後 $10^{5} \mathrm{CFU} / \mathrm{ml}$ となり, $5 \mu \mathrm{g} / \mathrm{ml}$ 以 上添加した培地では 12 時間後に $10^{7} \mathrm{CFU} / \mathrm{ml}, 24$ 時間 後には $10^{8} \mathrm{CFU} / \mathrm{m} l$ に達した。

S. pneumoniae はV V 因子を添加した培地にのみ発育 し， $5 \mu \mathrm{g} / \mathrm{m} l$ 以上添加した培地では增殖が良く $10^{8}$ $\mathrm{CFU} / \mathrm{m} l$ に達した。しかし $0.5 \mu \mathrm{g} / \mathrm{m} l$ 添加では增殖は 悪く, 24 時間後でも $10^{3} \mathrm{CFU} / \mathrm{m} l$ であつた。 X 因子の みの添加，および X 因子 V 因子をともに $0.5 \sim 500 \mu \mathrm{g} /$ $\mathrm{m} l$ 添加した普通ブイヨンではまつたく増殖が認められ なかつた。

$\mathrm{V}$ 因子を $50 \mu \mathrm{g} / \mathrm{m} l$ と一定にし，X 因子量を 0.05 $\sim 5 \mu \mathrm{g} / \mathrm{m} l$ と変えて添加した普通ブイョン中における S. pneumoniae の增殖性を検討した成績を図 3 に示し た。

$\mathrm{X}$ 因子を $5 \mu \mathrm{g} / \mathrm{m} l$ 以上添加した条件ではまつたく増 殖せず， $0.5 \mu \mathrm{g} / \mathrm{ml}$ 添加した培地では，菌株差はあるが 培養後 24 時間後においても $10^{3} \sim 10^{6} \mathrm{CFU} / \mathrm{ml}$ と十分 な増殖がみられなかつた。

また，図には示さなかつたが X 因子 $50 \mu \mathrm{g} / \mathrm{ml}$ を含 む普通ブイヨンに肺ホモジネート上清液を添加し，S. pneumoniae を培養したところ，增殖はみられなかつ た。 
マウス肺および気管ホモジネート上清浓中の堌殖因子 の検討 :

肺および気管ホモジネート上清液を NADase で処理 し, 普通ブイヨンに添加した時の $H$. influenzae, $S$. pneumoniae の増殖性の成績を図 4 に示した。

H. influenzae, S. pneumoniae は NADase 未処理肺お
よび気管ホモジネート上清液の添加で増殖が認められる が，NADase 処理肺および気管ホモジネート上清液の 添加ではともに増殖は認められなかつた。

肺ホモジネート上清液中の $\boldsymbol{H}$. influenzue の堌殖阻 害因子の検討：

$\mathrm{X}$ 因子，V 因子をそれぞれ $50 \mu \mathrm{g} / \mathrm{ml}$ 含む普通ブイ
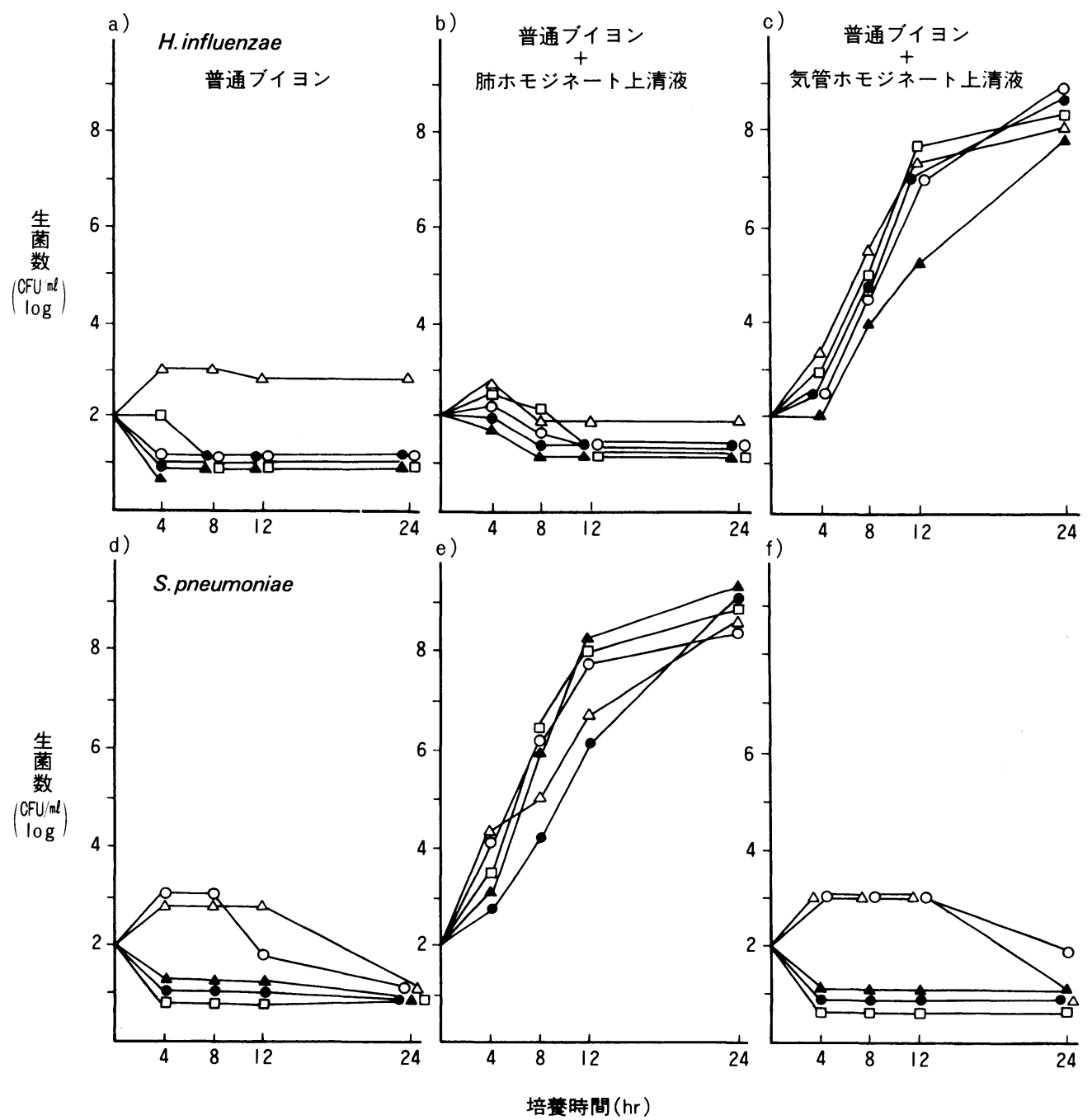

図 1 マウス肺および気管ホモジネート上清液の増殖に及ぼす影暗 菌株 : $\bigcirc \mathrm{H}$. influenzae $\mathrm{K}-14$

S. pneumoniae TMS 11

$\triangle H$. influenzae TMS 1

- S. pneumoniae TMS 12

$\square$ H. influenzae TMS 2

$\triangle S$. pneumoniae TMS 13

- $H$. influenzae TMS 3

$\triangle$ S. pneumoniae TMS 14

- $H$. influenzae TMS 4

$\square$ S. pneumoniae TMS 15 
ヨンに肺ホモジネート上清液を添加したときの H. influenzae の増殖性を検討した成績を図 5 に示した。

$\mathrm{X}, \mathrm{V}$ 因子を含む普通ブイョンでは $H$. influenzae の 増殖はよく, 培養 12 時間後では $10^{7} \sim 10^{8} \mathrm{CFU} / \mathrm{ml}$ に 達したが, 肺ホモジネート上清液を添加すると培養 8
時間まで増殖せず， 24 時間後でも約 $10^{5} \mathrm{CFU} / \mathrm{ml}$ レベ ルで増殖阻害が認められた。しかし, protease 処理肺 ホモジネート上清液の添加では $H$. influenzae の増殖は,

$\mathrm{X} \cdot \mathrm{V}$ 因子添加普通ブイヨンとほぼ同様な増殖を示し た。
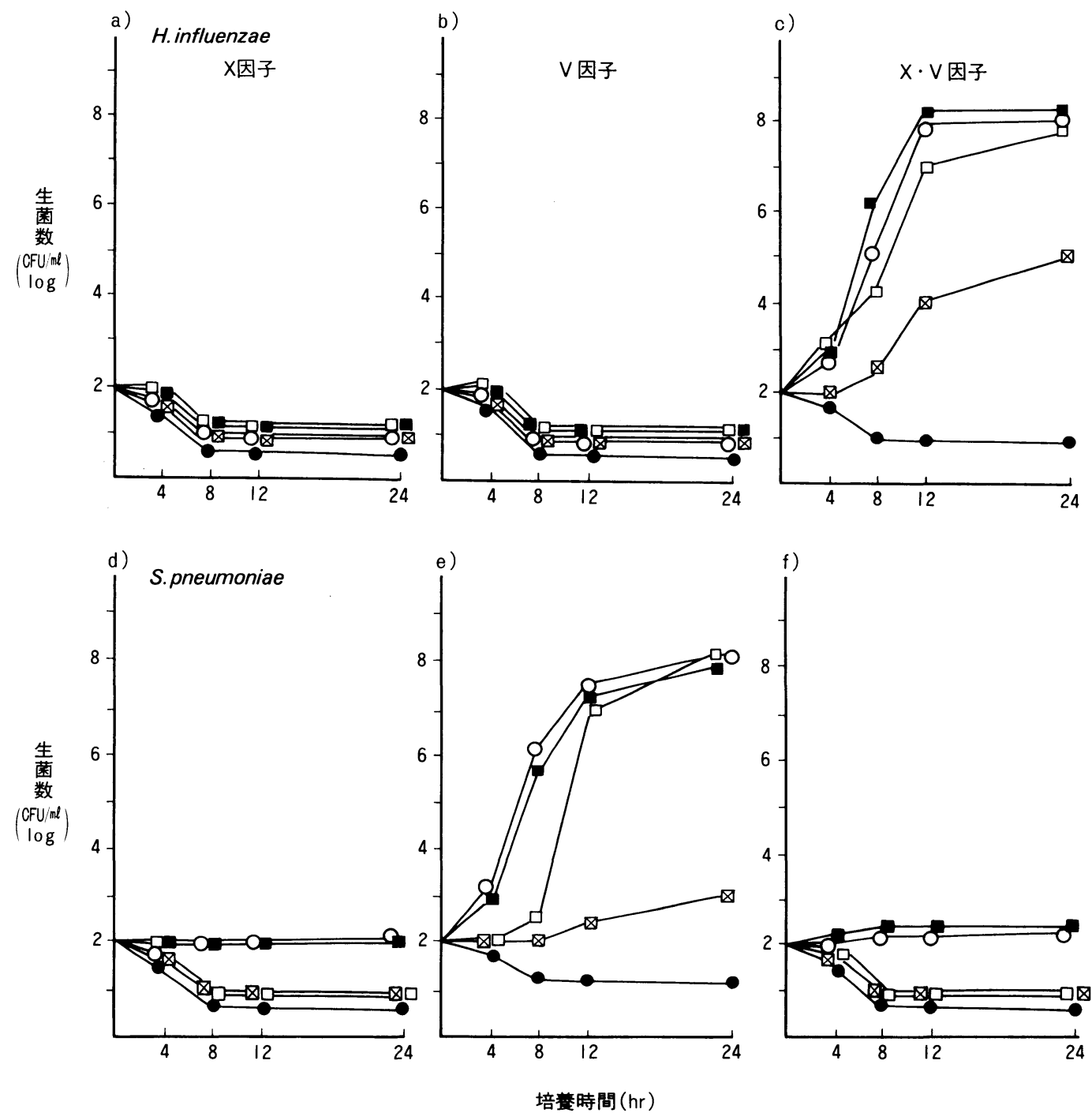

図 $2 H$. influenzae K-14 株と S. pneumoniae TMS 13 株の増殖に対する X 因子, V 因子の影響 培 地: 普通ブイョン X因子：ヘミン 濃度 $(\mu \mathrm{g} / \mathrm{m} l) \square 500$

V因子 : NAD

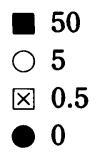



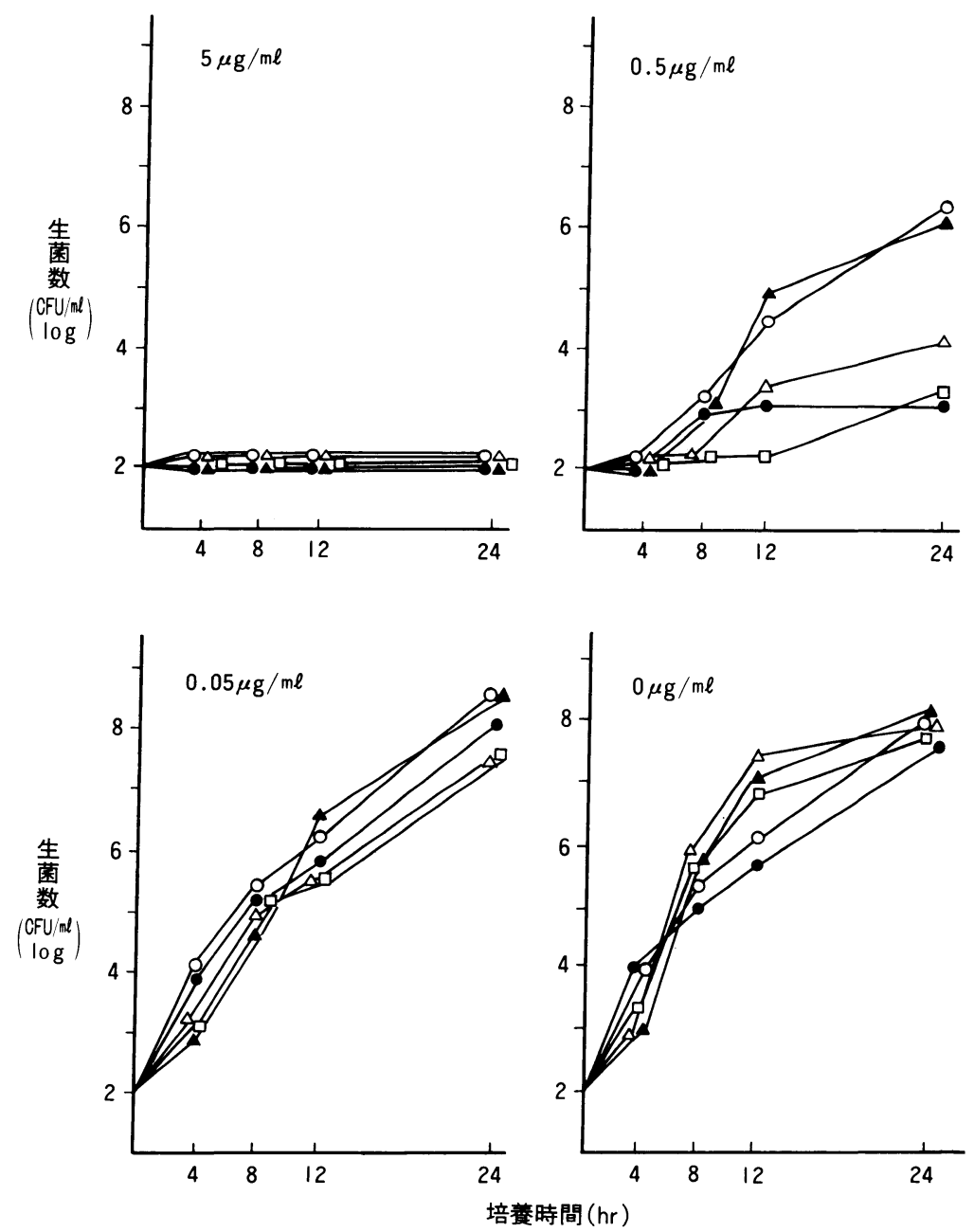

図 3 S. pneumoniae の増殖抑制に必要なへミン（X 因子）量 培地 : V 因子 $50 \mu \mathrm{g} / \mathrm{ml}$ を含む普通ブイョン 菌株 : $\bigcirc$ S. pneumoniae TMS 11

- S. pneumoniae TMS 12

$\triangle S$. pneumoniae TMS 13

$\Delta$ S. pneumoniae TMS 14

$\square$ S. pneumoniae TMS 15

考察

細菌感染症起炎菌中, 特定の組織で高頻度に感染を起 こす菌種の存在は臨床的に知られている4)。呼吸器感染 を起こす菌種の中です $H$. influenzae は主として気管支 炎を, S. pneumoniae は肺炎の起炎菌であることは多く
の臨床家が認めている。しかしこのよらに菌種により 感染組織に相違が生ずる原因については明らかにされて いない。松本らは $H$. influenzae の呼吸器感染を気道に おける過分泌と関連つけ, 気道分泌液中に本菌に対する 増殖因子が存在することを推論している3)。

H. influenzae の増殖因子としてはすでに X 因子 

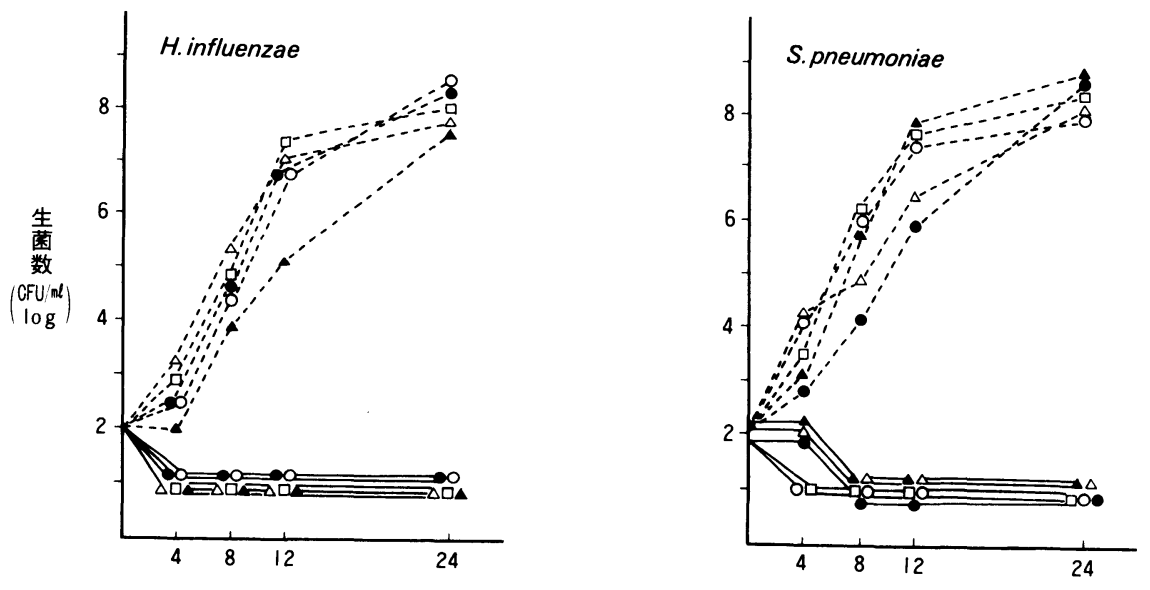

培益時間 $(\mathrm{hr})$

図 4 NADase 処理気管および肺ホモジネート上清液の増殖への影響

菌株 : $\bigcirc \mathrm{H}$. influenzae $\mathrm{K}-14$

$\triangle H$. influenzae TMS 1

$\bigcirc$ S. pneumoniae TMS 11

$\square H$. influenzae TMS 2

- S. pneumoniae TMS 12

- $H$. influenzae TMS 3

$\triangle$ S. pneumoniae TMS 13

$\triangle H$. influenzae TMS 4

$\triangle$ S. pneumoniae TMS 14

$\square$ S. pneumoniae TMS 15

NADase 処理気管ホモジネート上清液

NADase 未処理気管ホモジネート上清液

NADase 処理肺ホモジネート上清液

NADase 未処理肺ホモジネート上清液
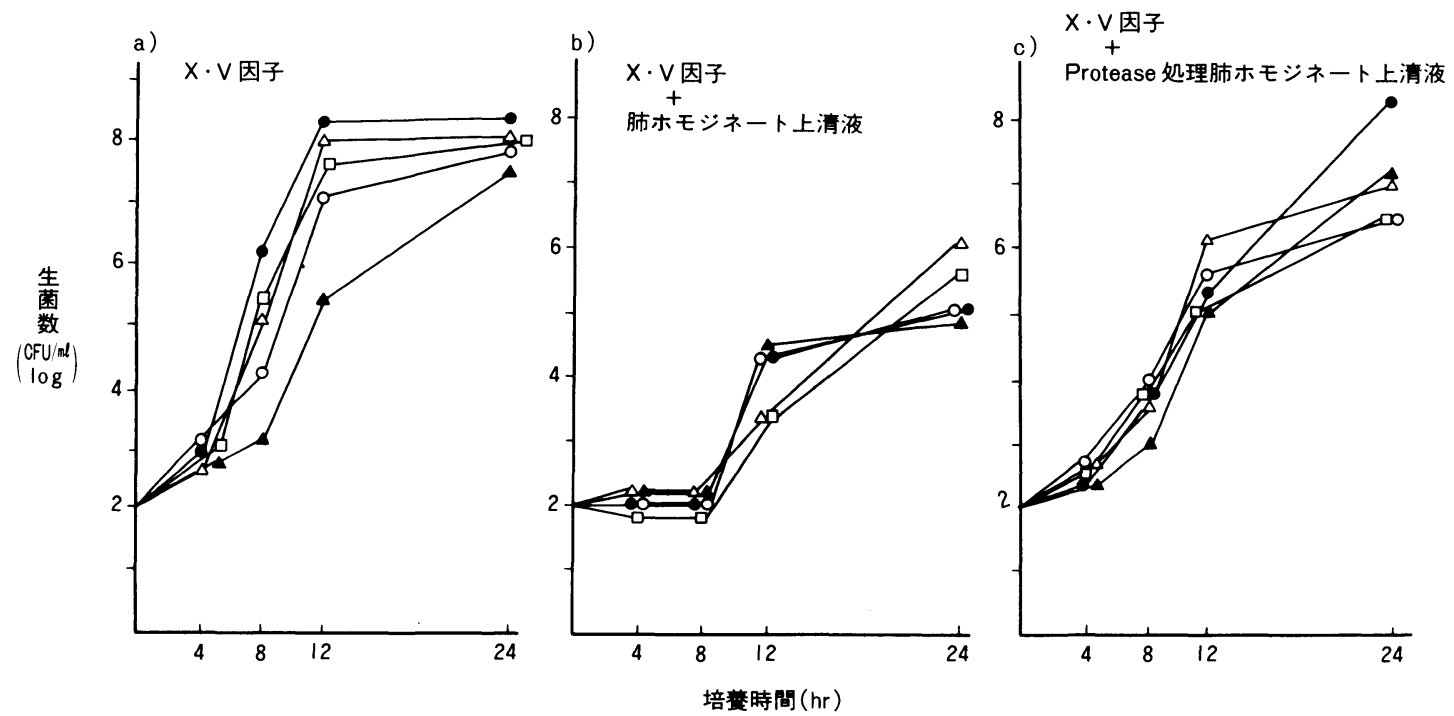

図 $5 \quad H$. influenzae の增殖に及ぼす肺および protease 処理肺ホモジネート上清液の影響 菌株 : $\bigcirc H$. influenzae $\mathrm{K}-14$

$\triangle H$. influenzae TMS 1

$\square H$. influenzae TMS 2

- $H$. influenzae TMS 3

$\triangle H$. influenzae TMS 4 
(hemin)，V 因子（ NAD）が知られている。本実験に おいて，マウス気管ホモジネート上清液を普通ブイヨン に添加すると $H$. influenzae の増殖が認められた。気管 ホモジネート上清液中には $15 \mu \mathrm{g} / \mathrm{ml}$ のX因子を chemiluminescence 法1)により確認しており, 普通ブイヨン に $10 \%$ 添加するため $1.5 \mu \mathrm{g} / \mathrm{m} l$ が培地中に含まれる ことになる。この X 因子量は H. influenzae の增殖に 必要な量を満足していると考えられる。また NADase 処理気管ホモジネート上清液を普通ブイヨンに添加し, $H$. influenzae を $10^{2} \mathrm{CFU} / \mathrm{m} l$ 接種した実験で本菌が増 殖しなかつたことから, 気管組織中の V 因子の存在が 裏付けられた。

以上により，気管ホモジネート上清液の添加により， H. influenzae が増殖することは, 気管組織中に存在す る $\mathrm{X} \cdot \mathrm{V}$ 因子によるものと考えられた。

気道粘膜よりの $\mathrm{X}$ 因子, $\mathrm{V}$ 因子の分泌量は不明で, その量は宿主の状況によつて変動することが予想される が, 松本らの推論のように, 分泌物中の増殖に関与する 因子の存在が感染部位での菌の増殖に影響することの可 能性が示唆された。

一方, S. pneumoniae は気管ホモジネート上清液中で は増殖せず，気管組織中の $\mathrm{X}$ 因子が本菌の増殖を抑制 することが明らかとなつた。因 3 より X 因子 $0.5 \mu \mathrm{g}$ $\mathrm{l} l \mathrm{l}$ 以上で増殖阻害がおき，又肺ホモジネート上清液に $\mathrm{X}$ 因子を添加すると增殖阻害が起こることから正常な 気管では本菌の増殖は起こりにくいと考えられた。

さらに，今回の実験で新たに得られた知見の一つは， H. influenzae は肺ホモジネート上清液を普通ブイヨン に添加した培地で増殖しなかつたことである。肺ホモジ ネート上清液中の V 因子の存在は, NADase 処理肺 ホモジネート上清液添加実験で間接的に証明されたが,

$\mathrm{X}$ 因子については肺組織中の微量の血液混入が避けら れないため，正確な測定值を得られなかつた。しかし， $H$. influenzae は $0.5 \mu \mathrm{g} / \mathrm{ml}$ 以上の $\mathrm{X}, \mathrm{V}$ 両因子が存在 しないと増殖できないこと，S. pneumoniae は $0.5 \mu \mathrm{g}$ $/ \mathrm{m} l$ 以上の $\mathrm{X}$ 因子の存在で增殖が阻害されること, 図 5 の実験に打いて, H. influenzae は 8 時間目以後は增 殖を始めており, 肺ホモジネート上清液中の $H$. influenzae に対する増殖阻害物質と $\mathrm{X}$ 因子の欠如は, 增殖 に対する影響が違つていることなどから，肺ホモジネー ト上清液中には X 因子は存在しないか, 存在しても $0.5 \mu \mathrm{g} / \mathrm{m} l$ 以下の微量と推測された。また, 肺ホモジ ネート上清液中の $H$. influenzae に対する增殖阻害物質 は protease 処理，あるいは熱処理によつて失活したた
めたんぱく性物質と推定されたが，この阻害因子の本態 については今後の検討課題と考えている。

S. pneumoniae は一般的に普通培地には増殖できない ので血液あるいは血清の添加が必要であるとされてい る9)。しかし，本実験に拈いてV 因子の単独添加によ つて本菌が十分に増殖することをみとめ，さらに X 因 子はある浱度以上 $(0.5 \mu \mathrm{g} / \mathrm{m} l)$ では增殖阻害作用を示す ことが明らかとなつた。

S. pneumoniae は $0.5 \mu \mathrm{g} / \mathrm{m} l$ の X 因子の存在で増殖 が阻害されるが，気管ホモジネート上清液中の X 因子 量は約 $15 \mu \mathrm{g} / \mathrm{m} l$ で培地中では $1.5 \mu \mathrm{g} / \mathrm{m} l$ となり十分な 阻害量が存在する。また S. pneumoniae の増殖阻害作 用は血球や hemoglobin では代用できず hemin でのみ 認められた。

これらの成績は $S$. pneumoniae の増殖には $0.5 \mu \mathrm{g} / \mathrm{m} l$ 以上の $\mathrm{V}$ 因子が必要であり,一方, $0.5 \mu \mathrm{g} / \mathrm{m} l$ 以上の $\mathrm{X}$ 因子により增殖阻害が生ずることを示している。

本報告における $H$. influenzae および S. pneumoniae の増殖性の特徵がヒトの感染発症の実態にどれほど関与 するかは現在のところ不明である。しかし，本実験で明 らかになつた事実は, 少なくとも正常な気管では $S$. pneumoniae は増殖しにくく, 肺では $H$. influenzae は 増殖しにくい条件の 1 つとして, 気管扰よび肺組織中 の $\mathrm{X}$ 因子, $\mathrm{V}$ 因子の存在が何らかの関係を有している 可能性が示唆された。もちろん, ウイルスなどの感染が 先行して, 気道, 肺の分泌状況が異なるとき，これらの 増殖因子, 増殖阻害因子の存在も変動すると思われる が，今回明らかにされたマウス組織中の増殖因子，増殖 阻害因子はヒトの気官組織にも存在する可能性が考えら れ, 感染発症に何らかの影響を与えるものと考える。

\section{謝辞}

稿を終わるにあたり，御指導，御校閲を賜わつた五島 瑳智子教授に深謝いたします。また御協力をいただいた 微生物学教室の皆様に感謝いたします。

\section{文献}

1) Ewetz, L., and Thore, A. (1978) : Correlation between hemin content and the chemiluminescent luminol reaction with bacteria Appl. Environ Microbial. 36, 790-793.

2) George, R. C., Broadbent, D. A., and Drasan, B. S. (1983) : The effect of influenza virus on the adherence of Haemophilus influenzae to human cells in tissue culture. Brit. J. Exper. Pathol., 64, 
655-664.

3）松本慶蔵（1974）：インフルェンザ菌性慢性呼吸器 感染症の基礎的 · 臨床的研究, 感染症学雑誌, 48, 117-124.

4) 松本慶蔵 (1984) : Bacterial adherence 一呼吸器感 染症を中心に一，感染·炎症·免疫，14, 155-165.

5）松本慶蔵, 宇塚良夫, 田口幹雄, 隆杉正和, 力富直 人, 永武 毅, 渡辺貴和雄, 山内壮一郎 (1984)： 喀痰内細菌叢定量培養法（喀痰定量培養法一 $\geqq 10^{7}$ $/ \mathrm{ml}$ の意義と再検討)，メディアサークル，29， 181-198.

6）松本慶蔵, 西岡さよ, 宇塚良夫, 木村久男, 助川善
兵衛, 渡辺貴和雄 (1973)：原因菌の変遷（2）喀痰内細菌数の定量培養成績より見た呼吸器感染症 —モダンメディア，19, 245-252.

7) 谷本晋一 (1984): 呼吸器感染症の診断と治療の現 況, Prog. Med., 4, 299-305.

8）螺良英郎, 後東俊博, 上田聡一郎 (1979): 気道, 肺に打ける感染防禦機構, 最新医学, 34, 25502555.

9) Willson, G. S., and Milles, A. (1974) : Topley and Wilson's Principles of bacteriology, virology, and immunity (6th edition), London Arnold Ltd.

\title{
Growth factors and inhibitors for Haemophilus influenzae and Streptococcus pneumoniae in the supernatants of mouse trachea and lung homogenates
}

\author{
Susumu KITAYA and Shuichi MIYAZAKI
}

\section{Department of Microbiology, School of Medicine Toho University}

We examined supernatants of mouse trachea and lung homogenates for the effects on the growth of $H$. influenzae and $S$. pneumoniae and obtained the following results:

$H$. influenzae grew in nutrient broth containing supernatant of mouse trachea homogenate and the same medium containing $\mathrm{X}$ and $\mathrm{V}$ factors; however, it didn't grow in the same medium containing supernatant of mouse lung homogenate or the mouse trachea homogenate treated with NADase. S. pneumoniae grew in nutrient broth containing either supernatant of mouse lung homogenate or $\mathrm{V}$ factor; however, it failed to grow in the same medium containing supernatant of the mouse trachea homogenate, $\mathrm{X}$ and $\mathrm{V}$ factors, $\mathrm{X}$ factor and supernatant of mouse lung homogenate, or supernatant of lung homogenate treated with NADase.

Supernatant of mouse trachea homogenate may contain both $\mathrm{X}$ and $\mathrm{V}$ factors necessary for stimulating the growth of $H$. influenzae. The presence of $\mathrm{X}$ factor in it was the cause of inhibition of the growth of $S$. pneumoniae.

Supernatant of mouse lung homogenate contained $\mathrm{V}$ factor, stimulating the growth of $S$. pneumoniae and $H$. influenzae, but not $\mathrm{X}$ factor. Some protain inhibiting the growth of $H$. influenzae may be present in supernatant of lung homogenate. 